\title{
The Legitimate and Illegitimate Offspring of English
}

\author{
Salikoko S. Mufwene, University of Chicago
}

\section{Introduction}

In this essay I pursue some of the questions discussed in Mufwene (1994), in which I argue that the naming practice of new Englishes has to do more with who have appropriated and speak them than with how they developed and how different they are structurally from each other, hence with how mutually intelligible they are. ${ }^{1}$ The title I have chosen is not a position stated explicitly by any student of the history of English. Rather it is a position suggested by how we have distinguished the different varieties, especially in our hypotheses on their developments, as we have typically downplayed the role of contact in the case of "native" Englishes but have invoked it, more or less as an irregular explanation, in the case of creoles and indigenized Englishes.

In fact, the distinction in the title is negatively correlated with how much we have learned about the different varieties of "new Englishes" (Mufwene 1994) from a genetic point of view (Mufwene 1996a, 1996b). I claim that we know more about the varieties which our practice has presented as "illegitimate offspring" or "children out of wedlock," i.e., Creoles and the indigenized varieties which have attracted most of our attention, than we do about the "legitimate" or "native" varieties (e.g., American or Australian English), which developed putatively according to the expected pattern of filiation (from a single parent) and are assumed to be normal or ordinary offspring (based at least on the language of Hock \& Joseph 1996). As in Mufwene (1996a, 1996b), I submit that the same kinds of restructuring processes (as part of the diachrony of a language) are involved in the development of both kinds of varieties, subject to varying ecological conditions, in which new dialect and language contacts play an important role (Mufwene 1996c). ${ }^{2}$ I continue to assume that, although there is no consensus on how Creoles have developed, what we have learned in discussing them should help us approach the development of other varieties of English more adequately.

Consistent with Mufwene (1994), I continue to see an undeniable correlation of race of speakers with the distinction presented in the title of this paper. The legitimate offspring are roughly those varieties spoken typically by descendants of Europeans around the world, whereas the illegitimate ones are those spoken primarily by populations that have not fully descended from Europeans. Those who are not happy with this dichotomic distinction may also consider distinguishing the offspring of English on a continuum. One of its poles consists of varieties which are spoken typically by descendants of Europeans and whose legitimacy has hardly ever been disputed. The other pole consists of English pidgins and Creoles, which have been stipulated as separate 
languages, despite their speakers' claim that they too speak English (Mühlhäusler 1985, Mufwene 1988). ${ }^{3}$ In the middle range come varieties characterized as "non-native" or "indigenized." 4 Below, I show how pernicious this practice is, starting with how the different varieties are named.

\section{An Insidious Naming Tradition}

The labeling of non-pidgin and non-Creole varieties spoken primarily by non-Europeans tells much of the story. The term non-native is one for disfranchising the relevant varieties as not really legitimate offspring of English, because their norms are set by non-native speakers. Indeed most of the children born to such communities, as in India and Nigeria, inherit the norms set by their second-language-speaker parents, thus making clear that native competence has to do more with norm-preserving than with norm-setting (Mufwene, in press-a). ${ }^{5}$ On the other hand, the term indigenized reflects the struggle for legitimizing them, a stand which is consistent with the position that every dialect has its own set of distinctive features and norms by which a speaker is identified as a typical or nontypical member of the community with which he or she is associated. Within this medium range of the continuum also fall varieties such as AfricanAmerican vernacular English (AAVE), whose status has been alternately associated with Creoles (hence the term "semi-Creole" branded by Holm 1988 and Schneider 1990), or with nonstandard dialects of English (e.g., Labov 1972, 1982; Fasold 1981).

I submit that the main reason for this apparently non-linguistic classification of offspring of English lies in the tradition of genetic linguisticsnot justified, as far as I can tell-to assume only a single parent in the filiation of languages. Accordingly, the speciation of mother languages into daughter languages has been discussed under the assumption that no intercourse was necessary with other languages prior to the production of offspring. To my knowledge, the typical explanation for innovative or novel structural features has been internally motivated-change, i.e., an outcome of processes that took place in a language independently of what went on in any other language it may have come in contact with. (For instance, Thomason and Kaufman 1988, argue that Old English would have undergone several of the changes that affected it independently of its contact with Old Norse and Norman French.)

Even contact among dialects within the relevant languages (e.g., Trudgill 1986, regarding especially Australia and the Falkland Islands; Algeo 1991, in the case of English in North America) seems to have been of no significant explanatory interest in traditional genetic accounts of new native Englishes. ${ }^{6}$ Accordingly, the Germanic languages are different among themselves apparently by some accident of patterns of speciation. Even if contact with other genetically unrelated languages may be overlooked, it does not seem to have mattered at all in this tradition that there was likely internal variation within Proto-Germanic itself, and subsequently within West-Germanic and later within the language(s) of the Jutes, Angles, and Saxons, and that subsequent contacts among these 
varieties would account for the speciation of Germanic into today's diverse Germanic languages and diverse dialects of English. In the same vein, it seems to have been of little significance to Anglicists that the Celts inhabited England before the Jutes, Angles, and Saxons invaded it and imposed their language varieties. Thus, internally-motivated change and ecology-free speciation have not explained everything. Instead, they have suggested in the development of new, "native" and "non-native," Englishes processual differences which are artificial from a genetic point of view. I return to this matter below.

\section{How Language Contact Has Been Downplayed}

Cases where it is so obvious that the speakers of the mother language came in contact with speakers of other languages which disappeared but left traces (called substrate influence) in the superseding language, such as the importation of Vulgar Latin by the Roman soldiers and administrators to what became today's France, Spain, and Portugal, are treated as rather exceptional. More often than not, only internally-motivated linguistic rules of change are invoked to account for the development of French, Spanish, and Portuguese, disregarding the role of the local Celtic languages, and in the case of French, of Germanic Frankish influence in triggering these changes.

Treated more exceptionally in this tradition are the Balkan languages, in which evidence of intense and multilateral population contacts over centuries could not be denied; and these have become the focus of studies of their structural features (although they are still not the "extreme" cases of restructuring that creoles are assumed to be). Regardless of the increasing number of such cases (see, e.g., Gumperz, and Wilson, 1971, for India), contact and convergence have become the plausible exceptional, rather than normal, explanation (e.g., Hock \& Joseph 1996). One may thus understand why contact, rather than possibly extensions of principles occurring in the lexifier (under specific ecological conditions, Chaudenson, 1989), has also been the explanation for the definitely untypical and would-be unnatural development of pidgins and creoles, and maybe also of indigenized Englishes. (Modern linguistics prevents us from assuming that some languages are less natural than others, or that they are not natural at all!)

Thus, as far as the history of English as spoken by descendants of Europeans is concerned, it has been normal not to have to ask why Celtic influence in English grammar is not obvious or why, where it is obvious, it is regionalized and confined to dialects of English which developed during the last three centuries or so, in particular Irish and Scots-Irish Englishes, or to dialects whose developers included speakers of the latter varieties (apparently as they were still developing), such as Appalachian English (Montgomery 1989). ${ }^{7}$ In the case of Irish and Scots-Irish Englishes, contact with other languages could not be denied, because it would otherwise be difficult to account for their structural divergences from the varieties spoken in England. But then one may raise the 
question of why these new varieties are characterized as "native," despite the influence of Gaelic.

The main reason is that the communities of those speaking them as vernaculars consist (almost) entirely of native speakers. To be sure, they must have been indigenizing during some phases of their developments. Given the acknowledged role of contact, one may ask why they are not called creoles, especially their nonstandard varieties. After all, creoles are considered native varieties, both in the above sense and in that of becoming indigenous to a community which has appropriated the new language variety (Hall 1966). To be equally insidious, why are creoles called separate languages for that matter? Since creolization is not a structural process (Mufwene 1986, 1996b, 1996c, in pressb) and the features of the varieties identified as Irish and Scottish are primarily nonstandard and are due to language contact, it requires some innocence not to invoke the race and location those who have appropriated English as an important tacit factor in the naming tradition. ${ }^{8}$

One may thus want to speculate whether there will ever be a time when Indian, Singaporean, and Nigerian Englishes may be considered "native?" Shouldn't we rather accept the reality that English is less likely to replace the indigenous lingua francas of these territories than it did in Wales, Ireland, and Scotland, because the sociopolitical ecological conditions are not the same? It is especially interesting that the varieties identified as "indigenized" are spoken in former exploitation colonies, whereas native Englishes are spoken in settlement colonies, in which assimilation policies have endangered, if not totally replaced, the indigenous languages and have eliminated from the competition most of the non-indigenous languages that English came in contact with. Challenging the "native"/"nonnative" distinction linguistically is significant that it presupposes that norms are not necessarily set by native speakers, only by those who speak a particular variety on a regular basis. Mufwene (in press) shows that indigenized Englishes and expanded pidgins do have stable norms that have been established and perpetuated by populations of primarily nonnative speakers. Such relities suggest that the "native"/"nonnative" distinction applied to language varieties, rather than to speakers, serves some social ideology more than it sheds light, if at all, on language change.

\section{The Development of English in England: When Does Substrate Influence Matter?}

Assuming that creoles developed by natural restructuring processes, only in ecological conditions that determined different outcomes from other contacts in the spread of European languages around the world, we may want to reexamine those "ordinary" or "natural" (i.e., non-exceptional) cases of genetic filiation and try to understand whether contact-based explanations do not really apply to them and whether we are really dealing with different restructuring processes in the development of creoles, indigenized Englishes, and native Englishes. 
Note that I do not wish to reactivate the incorrect hypothesis that French developed by the creolization (if only this were a structural process!) of Vulgar Latin or that Middle English developed by creolization out of the contact of Old English with French. I will support Thomason and Kaufman's position against the creolization-of-Old-English hypothesis with the following arguments: first, it is French which would have creolized, not English; second, the English did not shift overall to French as their vernacular (although a handful of them who lived in the Norman courts/circles may have) $;{ }^{9}$ third, the Normans who shifted to English could certainly acquire English very competently, not any worse in general than nonnative speakers of English living in North America or in the United Kingdom acquire English if they are well integrated in these societiestheir children must have definitely spoken English as natively as the English children. (See also Lüdtke, 1995)

To be sure, something ethnographically similar to creolization obtained in the development of Romance languages, in that the Celts shifted to the thenGallicizing Vulgar Latin, although they did not leave their motherland. However, I do not wish to talk about creolization at all, for the simple reason that it is not a restructuring process. It is just a social phenomenon, which alone does not explain how new varieties developed that are called creoles. And, I reiterate, the processes which produced creoles may be observed in the developments of other languages too, as also noted by Hock and Joseph (1996:15).

On these assumptions, I will make some observations and ask some interesting questions, starting with a comparison of the spread of Vulgar Latin and that of the language of the Jutes, Angles, and Saxons. Vulgar Latin, which was exported to the Celtic-speaking countries of continental Europe west of the Alps is a name for vernacular Latin, as a distinct variety from Classical Latin, the counterpart of standard varieties of European languages today. It probably was no more vulgar than the ancestor of English brought to England from Denmark and northern Germany, and in both cases soldiers were involved. The reason why Vulgar Latin was so influenced by the Celtic substrate and became French, Spanish, or Portuguese (depending on where the contact took place) certainly had to do with its appropriation by the colonized Celts. ${ }^{10}$ This appropriation process and shift to the dominant group's language is not different in kind from what has produced creoles and indigenized Englishes. Indeed, Thomason and Kaufman (1988) recognize the importance of language shift in both the case of the development of indigenized varieties and that of creoles.

Since at first glance one may perceive similarities in the domination of England, France, Spain, and Portugal by foreign powers, the following question arises: Why did not the same thing happen in England until after the seventeenth century, during the colonization of Wales and Ireland in particular? Note that England was invaded in the fifth century. ${ }^{11}$ Crystal (1995) seems to give an interesting reason, although he does not discuss the development of Romance languages at all. The Jutes, Angles, and Saxons settled in England in more or less the same way the Europeans settled in North America, not mingling with the native populations but pushing them further away from their settlements or 
killing them, more by the spread of Old World diseases than in wars (Crosby, 1992). As Crystal observes, the Germanic invaders called the native Celts Welsh "foreigners" (the etymological connection of the term with the Gallic tribe now called Walloons not withstanding) and did not mingle with them. The native Celts were no more eager to appropriate English in their homeland than the Native Americans wanted to shift to European languages. It is changes in socioeconomic conditions which led them to shift, several centuries later, to the invaders' language; and when they did there was substrate influence. The social integration of the Celtic populations in the frontiers of the British Isles, coinciding with the development of potato plantations there and the imposition of English as the rulers' language, then produced varieties such as Irish and Scots-Irish Englishes (Harris, 1991; Filppula, 1991).

One can understand why there is no Native American structural influence in North American varieties of English: Native Americans were not integrated in mainstream American society until recently, as minorities, and under socioeconomic pressures from the majority. To date, there are still Native Americans who speak English nonnatively, while most of their children, who are more fully integrated in the dominant culture, speak American English natively. Thus the Native American influence on North American English remains lexical and in discourse strategies (cf. Mithun 1992).

\section{The Significance of Ethnographic Ecology}

As I argue in Mufwene (1996d), ecology becomes an important explanation we cannot continue to overlook in our accounts of linguistic change and language speciation. The English language became creoles in some parts of the world because it was appropriated by other groups in ethnographic conditions that favored the development of new nonstandard varieties, owing in part to substrate influence, according to principles tentatively explained in Mufwene (1996c). ${ }^{12}$ Substrate influence was possible especially when the language's new speakers used it also, and perhaps mostly, to communicate among themselves, having less access to corrections from the native speakers of the metropolitan or the then-koineizing early colonial varieties. One must remember that creoles are different also because of the nonstandard nature of their lexifiers, in contrast with the primarily standard or scholastic lexifier of indigenized Englishes. This difference is enhanced by the typical heterogeneity of the lexifier (less codified and homogenized than the standard transmitted through the classroom) in the case of creoles. (See Gupta, 1991, on the nature and "nonnative" model speakers of the "school of English" introduced in Singapore. She emphasizes the role of Eurasians and non-British European teachers in the development of this indigenized variety.)

The demographic disproportion of speakers of the lexifier, constituting a small minority, relative to the population shifting to and appropriating it as their vernacular must be contextualized and related to integration of the population. For instance, AAVE developed in North America not because there 
were not enough speakers of English that one may have learned the language from, but because regular interaction with native speakers or norm-setters in the white communities was precluded by segregation. Let us also note that segregation in North America continues to this date, as speakers of AAVE continue to live in their own communities and interact primarily among themselves, even if they may acquire another variety for communication with non-members of these communities and/or develop passive competence in the variety used in the media.

Segregation as an ethnographic factor undermines claims that AAVE has been converging with white American varieties of English putatively by loss of some creole's basilectal features. The fact that African Americans have developed and preserved a host of other cultural peculiarities supports this observation. For instance, they have different prayer and religious celebration styles, different music and dance styles, different cooking/catering styles, and different dress styles, which all converge to mark a different ethnic identity. This is not to deny that the sources of some of these features may well be shared with some cultural features of white communities. Nonetheless, some African-American linguistic and nonlinguistic characteristics are different enough to consider them as diverging from the white traditions and having autonomized in ways specific to the ethnic group. ${ }^{13}$

A careful examination of settlement patterns in North America also shows that variation in ethnographic-ecological conditions of the founder population accounts for differences among (nonstandard) dialects of white Americans. According to Bailyn (1986) and Fischer (1989), homestead communities of early colonial New England more or less preserved ways of East Anglia, from where the vast majority of them had migrated in conservative and financially selfsupporting family units. Interacting primarily among themselves in the farm communities which they developed, they preserved most of their motherland's speech ways, restructuring it only minimally into a new variety of English. One may understand why New England English is assumed to be the American variety that is the closest to British English.

On the other hand, colonies of the Chesapeake Bay (Virginia, Delaware, and Pennsylvania) were settled by fewer family units, consisted of a large proportion of indentured labor (50-75\% according to Kulikoff, 1991), and were dialectally more heterogeneous. Although a large proportion came from the London area (Bailyn, 1986), London was itself a contact setting to which several jobless peasants and artisans had migrated from different parts of the British Isles, including the frontier regions of Ireland and western Scotland lowlands. Part of the indentured labor also came from continental Europe, especially Germany. Competition and selection of structural features produced a variety of English different from that of New England and more different from British dialects, although specific features have been traced to different parts of the United Kingdom. ${ }^{14}$

Communities such as in the Appalachian mountains with larger proportions of Scots-Irish founder populations developed varieties of their own (Montgomery 
1989). Chambers (1991) reports similar things about varieties of English in Canada in which an Irish element is identifiable. One may propose similar explanations for the development of Italian English, Jewish English, and the like, assuming a social integration parameter which would favor more divergence from other developments.

Where segregation was implemented in the strongest form, the strengths of factors bearing on feature selection was shifted more dramatically, even if the lexifying input was more or less the same, so that Celtic, or German, or Dutch influence would be stronger in some communities than in others, consistent with the interpretation of influence from outside the lexifier as the role which any such language may have played even only in favoring the selection of a particular structural feature over other alternatives in the lexifier itself. Thus, the selections made in the different varieties would not be identical, and where they are almost identical, such as between AAVE and white American Southern English, rules do not apply in exactly the same ways, e.g., the invariant be and the perfect done plus past participle or past tense rules.

Schneider (1989, and earlier work), Poplack \& Tagliamonte (1991, 1994), and Tagliamonte and Poplack $(1988,1993)$ have shown that there are many more similarities than have been admitted in part of the literature on the subject matter. Such considerations are one more reason for arguing that there are many more similarities in the restructuring processes that produced all these varieties, that the distinction between internally and externally-motivated changes sheds no significant light on how restructuring itself proceeds (despite differences in causation), and that none of the new Englishes should be treated as children out of wedlock. The ecological model advocated here and Mufwene (1996c, 199d) just makes it possible to account for differences where there are some, even mere statistical ones. These differences matter to the extent that they reflect how diversely competing alternatives may be weighted in different communities in order of preference or likelihood of using one or another variant.

\section{Mutual Intelligibility and the Contact History of English}

In the end, one must concede that everywhere "the story of English" has been a history of contacts, of mixing and competition of features from diverse varieties, and of selections determined in part by the variants then available in English itself and in part by the systems previously familiar to some of the nonEnglish populations who were appropriating it as their vernacular. Note that variation in the nature of the lexifier is an important factor, and we cannot continue to assess restructuring in creoles, AAVE, and indigenized Englishes using the same reference system for comparison. For some varieties, the lexifier was nonstandard, while for some others, it was a standard variety. Such variation alone set the stage for different outcomes.

Unfortunately, the vast majority of the literature has generally disregarded or downplayed this ecological approach. English is generally expected to have changed relatively little in settings where descendants of its native speakers 
during the colonial days interacted intimately primarily among themselves and/or with other Europeans, as in North America, Australia, South Africa, and Argentina. Features of the new varieties have been related indiscriminately to British English, regardless of the dialectal diversity of their sources. Contact among the different dialects of English and with other originally non-anglophone European populations was not considered a factor, as long as the other Europeans shifted to English. In some cases facile explanations have been invoked to account for developments which seem too divergent: for instance, the myth that white American Southern English reflects corruption under the influence of the African population during the plantation economy era. ${ }^{15}$

Where English came in contact with non-European languages, especially in the sugar-cane plantations and rice fields on which creoles developed, or at the trade posts at which pidgins emerged, it has been too easy to invoke "unnatural" or "non-ordinary" developments (e.g., McMahon 1993; Hock \& Joseph 1996) or untypical factors such as children (Bickerton 1981 and later work) - assuming in the latter case a complete breakdown in the transmission of the lexifier, which produced pidgins, and the invention of a new system by children. I surmise that the appropriation and consequent restructuring of the lexifier by non-Europeans made it easier to accept such accounts at their face value and to indirectly disfranchise their new varieties under the pretext that they are not mutually intelligible with other varieties of English. ${ }^{16}$

It does not seem to have bothered linguists much that dialects of the same language need not be mutually intelligible. Nor do they seem to have been concerned by the fact that most speakers of such disfranchised varieties say they speak English. Certainly, if mutual intelligibility were such a critical criterion, over sharing an identifiable ancestor, there would be more reasons for treating Modern English varieties and English creoles as dialects of the same language than for lumping the former together with Old English while excluding creoles, as the following examples show. It is often easier to make sense of the creole and indigenized English texts than to interpret Old English ones.

\section{Some OLD ENGLISH constructions cited in Traugott (1972:72-73):}

Syle me ænne hafoc. 'Give me a hawk.' (AElfric's Colloquy 31.132, @ 1000 AD) Gap peawlice fonn ge gehyran cyricean bellan (Elfric's Colloquy 48.310, @ 1000 AD) 'Go devoutly when you hear of-church bells.'

Hwæłer ge nu secan gold on treouwum. (King Alfred, Boethius 73.24, 880-890 $\mathrm{AD})$ 'Do you now seek gold in trees?'

pa gefengon hie para preora scipa tu (Anglo-Saxon Chronicle 90.26, 880-890 AD) then they captured two of those three ships' 
2. Some MIDDLE AND EARLY ENGLISH constructions cited in Traugott $(1972: 119,144)$ :

Weither seistow this in ernest or in pley? (Chaucer: Knight's Tale A.1125)

Whether had you rather lead mine eyes, or eye you master's heels? (Shakespeare: Merry Wives of Windsor III.ii.3)

Sirra, take my word, I charge thee, for this man, or else goodman butterfly, Ile make thee repent it. (Deloney. Th. of Reading 313.18)

And in the same manere oure Lord Crist hath woold and suffred that thy three enemys been entred into thyn house ... and han ywounded thy doghter. (Chaucer: Tale of Melibee B.2615)

3. Some GULLAH constructions from Mufwene's field records (1980s): ${ }^{17}$

JR: You trow way... trow way wha? En one day, I gone down deh, en talk bout shrimp bin a bite! I bin on dat flat, en I had me line, I done ketch couple a whiting... I say, I ga put up da drop net... when I look up, duh look from yah to your car deh, I see sompin on da damn side da shoulder comin, like a damn log. I watch um, en when I see him gone down...

EL: $\mathrm{Hm} \mathrm{hm!}$

JR: En dat tide bin a comin in... en dat sucker swim close, closer en closer, den I look en I see dat alligator open e damn mouth!

4. Some Basilectal GUYANESE CREOLE constructions from Bickerton (1975: 42): 18

wel if di ded kom aal awi sa tek ded rait he

Well if death comes, all of us will die right here'

den yu go kaal fu boot an so yu a go a kriik

Then you will call for [a] boat and that's how you go up [the] creek'

hi sa pe di rent tu

He will pay the rent too'

if ani blak man fi kom in awi vilij fi mek eni trobl, dem go nak dis drom If any black man should come in[to] our village to make trouble, they would beat this drum.' 
5. Some Basilectal SINGAPORE ENGLISH constructions from Mary Gupta (1994): ${ }^{19}$

Whole life tell [people] you not [kiasu], then make so much noise only.' (p.8) You are always telling people you are not [obsessed with getting on], and then you make such a fuss.'

You put there[,] then how to go up? (p.11)

If you put [it] there, then how [can people] go up [the stairs]?'

I sit here talk, can hear also. (p.11)

I['ll] sit here [and] talk, [it (the tape recorder)]can pick up [my voice] too."

6. Some HIBERNO-ENGLISH constructions from Odlin (1992) and Filppula (1991):

Well, I seen the time you'd buy a farm for ... five or six hundred ... Seen farms selling and I young lad

But when the house is quiet and us alone you never heard such talk that's going on there.

He fell and him crossing the bridge. 'He fell while crossing the bridge.'

It was all thatched houses was here one time, you know.

Father and mother was givin' him hell. 'Twas in harvest time and the weather bad.

7. Some APPALACHIAN AND OZARK ENGLISH constructions from Christian, Wolfram, \& Dube (1988):

He just kept a-beggin' and a-cryin- and a-wantin' to come out.

That was the prettiest tree that ever he seen.

Well, I've just been lucky I never been bit.

Kerosene, that's suppose to been the cure for everything.

Seem like everybody knowed where I was from.

One of the lights had went out.

The girls is usually the ones who picks them.

I was scared to death after I done stepped on it. 
8. THE ARUMBAYA LANGUAGE According to Leslie Lonsdale-Cooper \& Michael Turner, the Translators of Hergé's The adventures of Tintin: The Broken Ear (1975):

Owar ya? Ts goota meecha mai 'tee.

How are you? It's good to meet you, matey'

Naluk. Djarem membah dabrah nai dul? Tintin zluk infu rit'h. Kanyah elpim?

Now look. Do you remember the brown idol? Tintin's looking for it. Can you help him?'

Dabrah nai dul? Oi, oi! Slaika toljah. Datrai b'gib dabrah nai dul ta'Walker. Ewuz anaisgi. Buttiz'h felaz tukahr presh usdjuel. Enefda Arumbayas ket chimdai lavis gutsfa gahtah'z. Nomess in'h!

The brown idol? - It's like I told you. The tribe gave the brown idol to Walker. He was a nice guy. But his fellows took our precious jewel. And if the Arumbayas catch him, they'll have his garters. No messing!

Example (8) is fictional and perhaps the only development which one may consider unnatural in settings where English has been appropriated by a foreign group. At age 8, my daughter gave up on trying to interpret it, despite her ability to read eye dialect, because she could not recognize any English words. This is indeed where the primary problem arises in trying to interpret this text, because the creators of this restructured English segmented the phonetic strings in ways that violate English word boundaries. It is interesting that no English pidgin or creole displays this kind of restructuring.

A problem with mutual intelligibility as a criterion that should help determine whether or not English has changed into a new language is that it really depends on which "native" variety is being compared with a creole, AAVE, or an indigenized variety. As stated above, AAVE and creoles developed from the contact of nonstandard varieties of English with other languages. Actually, once things are put in the right sociohistorical perspective, one must include in the structure of the lexifier, features of non-native varieties spoken by the Scots-Irish who worked as indentured labor in the colonies and interacted on a regular basis with the slaves or other non-European indentured labor. The intelligibility of these varieties must be determined not from the point of view of the educated varieties of English typically spoken by linguists but from the point of view of nonstandard varieties of English that developed among descendants of Europeans under similar conditions. Thus AAVE is more appropriately compared with nonstandard varieties of White American Southern English (e.g., Wolfram 1974; Schneider 1989 and earlier work), like African Nova Scotian English is compared with that of the local white communities (Poplack \& Tagliamonte 1991, 1994; Tagliamonte 1996; Tagliamonte \& Poplack 1988, 1993). It is really when speakers of such related varieties say they do not understand each other that we may establish for sure that these vernaculars 
are not mutually intelligible. After all, varieties of English spoken by descendants of Europeans are not a homogeneous lot, nor can we guarantee that any variety of, for instance, Australian English is mutually intelligible with any variety of American English.

As submitted in Mufwene (1994), most indigenized varieties of Englishabstracting the parts of their continua treated as pidgins (e.g., Tay, 1981) - have been lexified by standard and literary varieties through the scholastic medium. It is not surprising that they are largely intelligible to educated speakers from outside the communities where they are spoken. However, speakers of indigenized varieties who have interacted with native speakers of nonstandard varieties can probably attest to experiences in which they and their interlocutors failed to understand each other. And there are of course cases of such incidents between speakers of standard and nonstandard varieties of "native" Englishes. We have often also forgotten that mutual intelligibility is determined not only by structural similarities of the relevant systems but also by familiarity with the speakers and their systems. (Smith, 1992 is quite informative on the subject matter.) Familiarity applies even to cases where speakers of different languages understand each other. ${ }^{20}$

\section{The Cost of Capitalizing on Mutual Intelligibility}

While mutual intelligibility has been a powerful tool in disfranchising some new varieties of English, it has unfortunately also had some negative effects on research on the development of some other varieties. Today we may claim to know more about the development of pidgins and creoles, although a little less on the development of AAVE and indigenized Englishes, than we do about the development of "native" Englishes. As interested as we have been in the development of new "native" dialects, we have generally shown little interest in the ethnographic ecologies that produced them, except in a handful of studies. For instance, did British dialects come to coexist in the same ways in the colonies as they did in the British Isles before the colonization of territories outside Europe (Mufwene 1996b)? Did the new settlements favor the preservation of the dialects brought over from the British Isles, or did they rather favor the development of new ones out of novel patterns of contacts among speakers of varieties who were less likely to interact regularly with each other in the motherland? Which social and regional dialects were represented in the founder populations and to what extent did this factor influence the fate of English in the colonies? Did the new social structures favor or disfavor the spread of features from particular social classes and/or places? To what extent did the different waves of immigration influence the development of these new varieties? How indeed did "leveling" or "koineization," as claimed by some (e.g., Trudgill 1986; Montgomery, in press) take place? Would this be a different process from the feature-competition and selection model advocated in Mufwene (1996c) for creoles? Did the other European languages with which English came in contact, such as Dutch in the New Netherland, or German in Virginia, or 
French in Louisiana, influence the structures of the new "native" English varieties, how, and under what particular conditions? ${ }^{21}$

Had we been asking such ecologically relevant questions, we could have asked in what ways and to what extent the diachronic processes that produced new "native" Englishes were different from those that resulted in indigenized Englishes, for instance whether there is sub- and/or adstrate influence in new "native" Englishes. I surmise that feature-competition and selection were involved in the development of all new varieties, subject to ecological constraints peculiar to specific settings, but this must be verified (Mufwene, 1996b). There is little doubt in my mind that all new varieties of English are adaptive responses to new ethnographic and other cultural ecologies, but more work must be done to verify this conjecture.

\section{In Conclusion}

A brief review of a few things we have learned about the development of creoles will make it easier to reexamine the speciation of English into its numerous varieties from that perspective. One of the reasons why creoles have developed is not necessarily because some languages came to coexist in the same geographical areas, but because in the contact settings which produced them some speakers appropriated as their vernacular a language (variety) that was originally not theirs. In the process, they restructured it to some extent, subject to several ecological factors (structural and ethnographic). As explained in Mufwene (1996c), the whole population of those appropriating such a lexifier did not speak it uniformly, even in the restructured form it assumed (although there were similarities among speakers). The emerging creole was thus never homogeneous. Its putative communal homogeneity is a construct projected by the analyst, often of necessity, from structural similarities observed in texts from different sources or idiolects. Each creole is otherwise a set-theory union of several idiolects, as any language is for that matter, like a species is projected from a population of individuals (Mufwene 1996a).

Colonial English itself, the creoles' lexifier, was heterogeneous. Some of the variation within each creole and among them as a group is attributable to the lexifier's internal variation, either geographical or social. A reason for such heterogeneity is that the colonists migrated from different parts of the British Isles but did not always resettle with people of exactly the same geographical and social backgrounds. An advantage of analogizing 'language' with 'species', be it a creole or not, is that we can gauge whether variation remains stable (thus, there is no change) or whether it increases or decreases and under what particular ecological conditions. (There is no synchronic variation within an organism.)

Positing English in the British Isles as the original heterogeneous species, we may claim that creoles are the most conspicuous manifestations of increase in diversity, as they represent more obvious deviations from the original typical range of variation. The ecologies of their respective developments also enabled them to emerge as new subspecies, because they developed their own norms and 
became socially more autonomous (Chaudenson 1992; Mufwene 1996c). Creoles reached these norms as their predominantly non-European speakers accommodated each other, selecting structural features in and out of their respective idiolects and moving closer and closer to each other's systems, although the communal system never became monolithic. (This is evidenced by the literature on creole continua, on which see Mufwene, ed., 1997).

Much of the same processes took place among speakers of the other, noncreole colonial varieties of English (Trudgill, 1986). This explains why new "native Englishes" differ from varieties spoken in the United Kingdom, although one may determine the specific British origins of some of the features. Surely, English in the then British Isles underwent its own share of changes too, which were probably inevitable, given the important population movements and contacts which took place there during the same colonial period. However, such restructuring underscores the fact that dialectal and idiolectal features were engaged into new competitions which yielded different outcomes in different ecologies. The challenge lies in explaining the development of all these varieties, especially in figuring out the selection principles followed by those who produced them. The ecology-sensitive model of markedness used in Mufwene (1996c) addresses this question.

Variation remains an important language-internal ecological factor. It may direct the structure of a language (variety) into a new direction if its ethnographic-ecological conditions change, as was typically the case in the contact settings which European colonies constituted. Under new conditions, a new variety may emerge, as in the case of English pidgins and creoles, indigenized Englishes, and new "native" Englishes.

As must have become obvious by now, part of the external ecological factors is the set of structural options available in the other languages that English came in contact with. Such contacts could not only allow foreign elements into the changing system but also determine which variants in the overlapping idiolects and dialects from the motherland would be selected into the new variety. Even without the non-European factor, new contact patterns in the colonies among metropolitan varieties and the competition of features that ensued is an ecological factor internal to the changing language. An important difference in the developments of new "native" Englishes and the other new varieties lies thus in the nature and size of the pool of structural features that came to compete with each other, and in whether or not there was a foreign element that could determine differentially which of the competing features of the lexifier itself were selected into the new variety. These are but some examples of what there is in the ecology of a language which influences its development.

It is pernicious to continue suggesting in our scholarship that some new Englishes are legitimate offspring of an earlier stage of English and that some others are illegitimate ones, some sort of children out of wedlock. The processes that produced all of them are of the same kind, although not the same changes apply in all cases. The same feature-competition-and-selection process played a role everywhere, subject to ecological factors. All new Englishes are natural 
developments and legitimate offspring, although some look more like their ancestors than others do. In fact, so do descendants of the same ancestor vary among themselves in a species.

Contact within a language community and between a language and some others seems to have played a more important role in language change and speciation than genetic linguistics has traditionally accorded it. In both cases of contact within and contact with others, variation has been an important systeminternal ecological factor, just like in biological evolution. Insofar as variation is recognized, the role of individual speakers as agents of change cannot be overstated (Hagège, 1993). They bring their idiolects in contact and restructure them through their mutual accommodations. It is hard to imagine that "native" Englishes did not develop by the same principles as indigenized Englishes and creoles, except for how language ecology threw its dice on the fate of metropolitan English, just as ecology in population genetics determines the evolutionary path of the species.

\section{ACKNOWLEDGMENTS}

I am grateful to Victor Friedman and Anthea Gupta for kind feedback on an earlier version of this essay. I am alone responsible for all the remaining shortcomings.

\section{NOTES}

1 Consistent with the literature, I am assuming here, gratuitously, that sharing structural features matters more than being familiar with the other system. Reality actually shows that familiarity should matter more (see also Smith 1992), since it accounts for cases where people understand other languages-which may share (a) few features with their own-while they may not understand dialects of their own languages to which they have not been exposed (assuming gratuitously again that dialects of the same language share more features among themselves than with other languages).

2 To be sure, Hock \& Joseph (1996) claim more or less the same thing as I do, but they sound quite ambivalent as they do not really disavow the position I criticize here, despite their acknowledgment of the role of contact in determining the diachronic path of a language. They equivocate, treating Creoles sometimes as dialects of their lexifiers and at other times as separate languages. On p. 444, they speak of them as not being "ordinary" relative to varieties which are presumably more normally, or directly, descended from their lexifiers.

3 Like Hock and Joseph (1996), Crystal (1995) also equivocates on the genetic status of English pidgins and Creoles, stating that scholars do not agree on the subject matter $(106,108,344)$, but suggesting in his discussion and his count of speakers of English around the world that they are varieties of English. Even Turner (1949), who pioneered the African 
Substrate Hypothesis, identifies this vernacular as a "dialect," presumably of English. (However, see Alleyne 1980 for a different classification.) Creolists are perhaps the greatest culprits in the trend that has disfranchised pidgins and Creoles as separate languages from their lexifiers. Some, such as Keesing (1988:227), have also stated that they have developed by "unnatural" processes.

4 Interestingly, terms such as "indigenized English" are also intended not only to claim legitimacy, which such varieties have been denied (cf, e.g., Kachru, ed. 1992), but also to distinguish them, as having non-European educated norms, from the pidgin varieties, which are typically associated with little or no education (Mufwene 1994).

5 In Mufwene (in press-b), I argue, after Chaudenson $(1989,1992)$, that the norms of a language variety develop from its vernacularization (i.e., usage as a vernacular) in the community of its speakers, independently of whether or not it contains (a significant proportion of) children. The existence of conventions which are as rigorous and complex in communities with predominantly non-native speakers (e.g., Cameroon Pidgin English, per Féral 1989) as in communities with native speakers (e.g., Caribbean creoles) is indisputable evidence for this position.

6 Aside from especially Trudgill (1986), there are some interesting studies of dialect contact today which highlight the development of new varieties in England (e.g., Kerswill and Williams, 1994; Britain, 1996.) There is yet little literature on the fact that pervasive dialect contact was taking place in England during the colonization of the New World and other territories, which must have affected the shape of English in England itself. This is separate from the contact with Welsh and Gaelic around the same time, which has also produced new "native" varieties, such as Welsh and Irish Englishes. Other interesting contact perspectives on the development of North American English include Kahane (1992) and Heath (1992).

7 Based almost exclusively on phonetic considerations, Shackleton (to appear) argues that a lot of Southwest Virginia linguistic features attributed to Scots-Irish influence may simply have originated in southern England, where similar features are also attested. Still, he presents a scenario where competition and selection of features is an adequate explanation. In this case, a large proportion of the selected pronunciations are features shared by those southern varieties, especially those which were spoken in or around London.

8 South Africa is an interesting case, where the English spoken by descendants of Europeans (including Afrikaners) is said to be "native," whereas the varieties spoken by other South Africans are said to be indigenized, reflecting the colonial many-tiers sociopolitical ecology of the country,

9 French in England seems to have maintained the same position as English in most former British exploitation colonies, where it is typically spoken as a second-language and only by a small proportion of the population. Lüdtke's (1995) view that it is the English of Anglo-Normans, then shifting from French, which would have creolized is acceptable if one believes that creolization is a structural process. Note, however, that this diachronic process would have affected primarily one sociolect, of the upper class, but not the overall language. 
10 Scholars must still explain why, compared to the Celts in England, those on the mainland shifted so fast from their languages. Otherwise, the shift was a gradual process. Chaudenson (1992) reports that parts of France were still Gallicizing in the 17th and 18th centuries, during the French colonial expansion, around the same time Wales, Ireland, and the western lowlands of Scotland were apparently beginning to Anglicize.

11 As noted above, the Latinization of the Romance territories was as gradual as the Anglicization of the United Kingdom. Differences lie in the timing of the beginning of the language shift and in the extent of substrate influence.

12 I also explain there that substrate influence need not be interpreted as materials brought from the substrate languages. It probably consists in most cases of the fact that for some grammatical functions, convergence of some structural features of the heterogeneous lexifier with those of (some) substrate languages favored the selection of such features over other alternatives.

13 Some dialectologists will argue that the linguistic differences between AAVE and some nonstandard English dialects are more statistical than structural (see below) and perhaps more manifest prosodically. They may be right, but dialectal differences need not be numerous nor clear-cut. What may matter the most is how they are construed socially, and this social interpretation has influenced, if not determined, the direction of dialectological research in North America. Such observations by dialectologists do not of course question the basic position of this paper, which is to highlight similarities in the processes of restructuring which produced new English varieties, even commonalities in the sources of the features, but variation in the ethnographic ecologies which determined the selection of features.

14 One may thus consider German influence as a plausible explanation for the constructions John came with and John brought it with, parallel to Johan kam mit and Johan bracht es mit, respectively.

15 It is useful to remember that only 5-10 percent of whites in the American South owned plantations. According to Coleman (1978:39), "over three fifths of Georgia's [white] families owned no slaves at all." This suggests that the vast majority of white children were not looked after by African (-American) nannies. Segregation against (descendants of) Africans minimized influence from the latter group on the speech of whites, except in domains such as cooking, music; and street culture (Dillard, 1985), where this is still obvious. On the other hand, note that the Jim Crow laws were not passed until the mid 19th century, which suggests that there was more intimate social intercourse between at least the poor rural whites and the descendants of Africans until that time. Consequently, the preceding two centuries of regular interaction between the mostly rural black and white populations in the American South would have fostered the development of similar, though not identical, ethnic vernacular varieties between them, unlike in coastal South Carolina and Georgia, where segregation started much earlier.

16 Some scholars familiar with the debate on creole genesis may wonder why I have singled out the Language Bioprogram Hypothesis here. I continue to assume that the real influences in competition have been from varieties of the lexifier and from the substrate languages Mufwene (1990), consistent 
with my position that creole development is the outcome of normal language change under specific sociohistorical conditions (Mufwene 1996c).

17 I have used conventional eye dialect, making sure not to exaggerate differences between Gullah and English. $G a$ is pronounced [gə] and is so represented to keep it distinct as a marker of FUTURE from its cognate go. $D a$ and $d u h$ are homophones, pronounced [də], but are represented differently so that the former may be mechanically recognized as the definite article and the second as the DURATIVE/ PROGRESSIVE marker.

18 This text is in its original phonetic-spelling transcription commonly used by Caribbean scholars.

19 Despite what the title of the book suggest, I have selected only constructions form adult speakers.

20 Perhaps in relation to pidgins and creoles, indigenized Englishes may not be fully disenfranchised; after all, they seem more intelligible to speakers of "native" varieties of English. On the other hand, they are spoken typically in communities in which the vast majority of speakers and normsetters are not of European descent nor native speakers. In this respect they are also like AAVE, keeping in mind that residential segregation in American cities has kept the vast majority of its speakers from interacting regularly with populations of European descent, outside the workplace, and therefore from developing a common vernacular with them.

21 It is useful to re-read Dillard $(1985,1992)$ in this connection.

\section{WORKS CITED}

Algeo, J. (1991) Language. In The Reader's Companion to American history. Edited by Eric Foner and John A. Garaty. Boston: Houghton Mifflin. pp. 637-640.

Bailyn, B. (1986) The peopling of British North America: An introduction. New York: Random House.

Bickerton, D. (1975) Dynamics of a creole system. Cambridge: Cambridge University Press.

Bickerton, D. (1981) Roots of Language. Ann Arbor: Karoma.

Britain, D. (1997) Dialect contact and phonological reallocation: Canadian raising in the English fens. Language in Society, 26, 15-46.

Chambers, J. (1991) Canada. In English around the world: Sociolinguistic perspectives. Edited by Jenny Cheshire. Cambridge: Cambridge University Press. pp. 89-107.

Chaudenson, R. (1989) Créoles et enseignement du français. Paris: L'Harmattan.

Chaudenson, R. (1992) Des îles, des hommes, des langues: essais sur la créolisation linguistique et culturelle. Paris: L'Harmattan.

Christian, D.; Wolfram, W. \& Dube, N. (1988) Variation and change in geographically isolated communities: Appalachian English and Ozark English. Publication of the American Dialect Society 74.

Coleman, K. (1978) Georgia history in outline. Revised edition. Athens: University of Georgia Press.

Crosby, A. (1992) Ills. In Atlantic American societies: From Columbus through abolition 1492-1888. Edited by Alan L. Karras and J.R. McNeill. London: Routledge. pp. 19-39. 
Crystal, D. (1995) The Cambridge encyclopedia of the English language. Cambridge: Cambridge University Press.

Dillard, J. (1985) Toward a social history of American English. Berlin: Mouton.

Dillard, J. (1992) A history of American English. London: Longman.

Fasold, R. (1981) The relationship between black and white speech in the South. American Speech, 56, 163-89.

Féral, C. (1989) Pidgin-English du Cameroun. Paris: Peters/SELAF.

Filppula, M. (1991) Urban and rural varieties of Hiberno-English. In English around the world: Sociolinguistic perspectives. Edited by Jenny Cheshire. Cambridge: Cambridge University Press. pp. 51-60.

Fischer, D. (1989) Albion's seed: Four British folkways in America. New York and Oxford: Oxford University Press.

Gumperz, J. and Robert Wilson (1991) Convergence and creolization: A case from the Indo-Aryan/Dravidian border. In Pidginization and creolization of languages. Edited by Dell Hymes. Cambridge: Cambridge University Press. pp. 151-167.

Gupta, A. (1991) Almost a crele: Singapore colloquial English. California Linguistic Notes 23.9-21.

Gupta, A. (1994) The step-tongue: Children's English in Singapore. Clevdon: Multilingual Matters.

Hagège, C. (1993) The language builder: An essay on the human signature in linguistic morphogenesis. Amsterdam: John Benjamins.

Hall, R. (1966) Pidgin and Creole Languages. Ithaca: Cornell University Press.

Harris, J. (1991) Ireland. In English around the world: Sociolinguistic perspectives. Edited by Jenny Cheshire. Cambridge: Cambridge University Press. pp. $37-$ 50 .

Heath, B. (1992) American English: Quest for a model. In The other tongue: English across cultures, 2nd edition. Edited ed. by Braj Kachru. Urbana: University of Illinois Press. pp. 220-232.

Hergé (1975) The adventures of Tintin: The broken ear. Translated by Leslie Lonsdale-Cooper and Michael Turner. London: Methuen \& Co. Boston: Little, Brown and Company (1978).

Hock, H. and Joseph, B. (1996) Language history, language change, and language relationship. Berlin: Mouton de Gruyter.

Holm, J. (1988) Pidgins and Creoles. Vol. 1: Theory and structure. Cambridge: Cambridge University Press.

Kachru, B. (ed.) (1992) The other tongue: English across cultures. 2nd edition. Urbana and Chicago: University of Illinois Press.

Kahane, H. (1992) American English: From a colonial substandard to a prestige language. In The other tongue: English across cultures, 2nd edition. Edited by Braj Kachru. Urbana: University of Illinois Press. pp. 211-219.

Keesing, R. (1988) Melanesian Pidgin and the Oceanic Substrate. Stanford: Stanford University Press.

Kerswill, P. and Williams, A. (1994) A new dialect in a new city: Children's and adults' speech in Milton Keynes. Final Report on a project funded by the Economic and Social Research Council.

Kulikoff, A. (1991) Colonial economy. In The Reader's Companion to American history. Edited by Eric Foner and John A. Garaty. Boston: Houghton Mifflin. pp. 201-203. 
Labov, W. (1972) Is the Black English vernacular a separate system? In Language in the inner city: Studies in Black English vernacular. By W. Labov. Philadelphia: University of Pennsylvania Press. pp. 36-64.

Labov, W. (1982) Objectivity and commitment in linguistic science: The case of the Black English trial in Ann Arbor. Language in Society, 11, 165-201.

Lüdtke, H. (1995) On the origin of Middle and Modern English. In Linguistic Change Under Contact Conditions. Edited by Jacek Fisiak. Berlin: Mouton de Gruyter. pp. 51-53.

McMahon, A. (1993) Understanding language change. Cambridge: Cambridge University Press.

Mithun, M. (1992) The substratum in grammar and discourse. In Language Contact: Theoretical and empirical studies. Edited by Ernst Håkon Jahr. Berlin: Mouton de Gruyter. pp. 103-115.

Montgomery, M. (1989) Exploring the roots of Appalachian English. English World-Wide, 10, 227-278.

Montgomery, M. (in press) The koineization of colonial American English. In Proceedings of the 1992 meeting of the Atlantic Provinces Linguistic Association.

Mufwene, S. (1986) Les langues créoles peuvent-elles être définies sans allusion à leur histoire? Etudes Créoles, 9, 135-50.

Mufwene, S. (1988) Why study pidgins and creoles? Column. Journal of Pidgin and Creole Languages, 3, 265-76.

Mufwene, S. (1990) For the record, let us get some facts straight. (A reply to Derek Bickerton's letter). The Carrier Pidgin, 17, 2,3, 6-7.

Mufwene, S. (1994) New Englishes and Criteria for Naming Them. World Englishes, $13,21-31$

Mufwene, S. (1996a) African-American English, Caribbean English creoles, and North American English: Perspectives on their geneses. In Mid-America Linguistics Conference. Edited by Frances Ingeman. Department of Linguistics, University of Kansas. pp. 305-330.

Mufwene, S. (1996b) The development of American Englishes: Some questions from a creole genesis perspective. In Varieties of English Around the World: Focus on the USA. Edited by Edgar Schneider. Amsterdam: John Benjamins. pp. 231-264.

Mufwene, S. (1996c) The Founder Principle in creole genesis. Diachronica, 13, 83134.

Mufwene, S. (1996d) Language ecology and creole genesis. Meeting of the Society for Pidgin and Creole Linguistics. San Diego, January.

Mufwene, S. (ed.) (1997) English-to-pidgin continua. World Englishes, 16, 2.

Mufwene, S. (in press-a) Native speaker, proficient speaker, and norm. In Native speaker: Multilingual perspectives. Edited by Rajendra Singh. Sage Publications.

Mufwene, S. (in press-b) Jargons, Pidgins, Creoles, and Koinés: What are they? Pidgins and Creoles: Structure and status. Edited by Arthur Spears \& Donald Winford. Amsterdam \& Philadelphia: John Benjamins. pp. 34-69.

Mühlhäusler, P. (1985) The number of pidgin Englishes in the Pacific. Papers in Pidgin and Creole Linguistics No.1 Pacific Linguistics, A-72, 25-51.

Odlin, T. (1992) Transferability and linguistic substrates. Second Language Research, 8, 171-202. 
Poplack, S. and Tagliamonte, S. (1991) African American English in the diaspora: Evidence from old line Nova Scotians. Language Variation and Change, 3, 301-339.

Poplack, S. and Tagliamonte, S. (1994) $-S$ or nothing: Marking the plural in the African American diaspora. American Speech, 69, 227-259.

Schneider, E. (1989) American Earlier Black English: Morphological and syntactic variables. Tuscaloosa: University of Alabama Press.

Schneider, E. (1990) The cline of creoleness in English-oriented creoles and semicreoles of the Caribbean. English World-Wide, 11, 79-113.

Shackleton, R. (to appear). A quantitative comparison of the dialects of Éngland and the American Upper South.

Smith, L. (1992) The spread of English and issues of intelligibility. In The other tongue: English across cultures, 2nd edition. Edited by Braj Kachru. Urbana: University of Illinois Press. pp. 75-90.

Tagliamonte, S. (1996) Has It Ever Been 'Perfect'? Uncovering the grammar of early Black English. York Papers in Linguistics, 17, 351-396.

Tagliamonte, S. and Poplack, S. (1988) Tense and aspect in Samaná English. Language in Society, 17, 513-533.

Tagliamonte, S. and Poplack, S. (1993) The zero-marked verb: Testing the creole hypothesis. Journal of Pidgin and Creole Languages, 8, 171-206.

Tay, M. (1981) The uses, users, and features of English in Singapore. In New Englishes. Edited by John B. Pride. Rowley, MA: Newbury House. pp. 5170.

Thomason, S. and Kaufman, T. (1988). Language Contact, Creolization, and Genetic linguistics. Berkeley: University of California Press.

Traugott, E. (1972) The history of English syntax. New York: Holt, Rinehart, \& Winston.

Trudgill, P. (1986) Dialects in contact. Oxford: Blackwell.

Turner, L. (1949) Africanisms in the Gullah dialect. Chicago: University of Chicago Press.

Wolfram, W. (1974) The relationship of white Southern speech to vernacular Black English. Language, 50, 498-527. 